\title{
The Structural Wave: on "the Sincere Flattery to Technology" and Some International Fortune of Italian engineering in the Second Half of XX Century
}

\author{
Alessandro De Magistris ${ }^{1, *}$ \\ ${ }^{1}$ Department of Architecture and urban Studies, Politecnico di Milano, Milan, Italy \\ *Corresponding author. Email: alessandro.demagistris@polimi.it
}

\begin{abstract}
Rooted in a historical path with solid academic roots and conditioned by the economic policies of the fascist regime, in the post WWII period the Italian engineering culture, and Pier Luigi Nervi enjoined an extraordinary international fortune that crossed the borders of the Cold war. The paper intends to highlight some key-aspects of this complex phenomenon, which in itself represents a fundamental and only partially written page in the history of architecture characterizing the developments of the design culture in the years of the Cold War, both in the West and in the Socialist world and in the USSR in particular.
\end{abstract}

Keywords: Postwar design culture, Transdisciplinarity, Cold War, Italian engineering, Eastern Europe architecture.

\section{INTRODUCTION}

In a long essay published on "Architectural Review" in February 1960, the same year when Theory and Design in the First Machine Age - one of his most important books - was released, Reyner Banham remarked "the sincere flattery to technology" and "the almost fetishistic gaze shown towards certain categories of engineers" who enjoyed "an unprecedented status, both as collaborators of architects, and as creators of forms to be imitated [1]. Far from being isolated, the famous British critic's writing is part of a vast picture of articles that appeared in many international specialized magazines between the fifties and sixties of the twentieth century and reminds us of the particular cultural climate within which the 'Miracle' of Italian engineering was inscribed. In fact, the activity and research of Italian engineers, which hinged on a solid tradition of thought and was driven by the economic constraints and policies of the Fascist period, found itself operating in a panorama designed to welcome and enhance its capabilities [2], [3].

\section{MOVING TOWARDS THE GOLDEN AGE OF ITALIAN ENGINEERING}

Resulting from a process that was rooted in the peculiarity of the autarchie period during the 1930s, the Italian structural culture, basically aiming at exploring the potential of reinforced concrete, was active in a scenario that was eager to welcome and enhance its inventive and application skills. In these years, the ground was highly fertile to define new spaces and circumstances for engineering and architecture to meet, thus explaining the fortune of books such as Strukturformen der Modernen Architektur by Kurt Siegel (1960), read and translated into many languages [4]. This important work was readily published, among others things, also in Russian in 1965 ("Figure 1") [5]. 


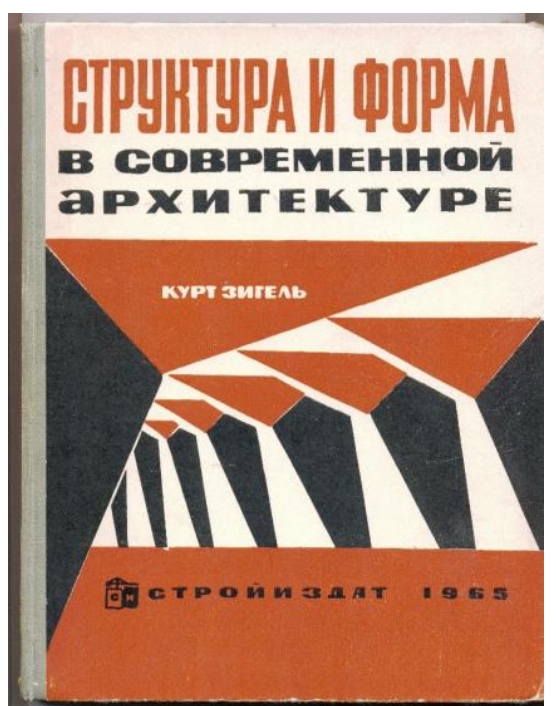

Figure 1 (BOOK COVER) K. Sigel', Struktura i forma v sovremennoj arkhitekture, Stroijzdat, Moskva, 1965.

The decades in which the Italian structural culture stood out, a culture that since the Gustavo Colonnetti and Arturo Danusso's lesson could express itself through the work performed by Pier Luigi Nervi, Riccardo Morandi, Silvano Zorzi, Segio Musmeci and other personalities, represented a sort of "Golden Age" to the relationships and interactions between engineering and architecture, marked by the fertilization of the relation between structural visions forms and inventions and architectural expressions ("Figure 2").

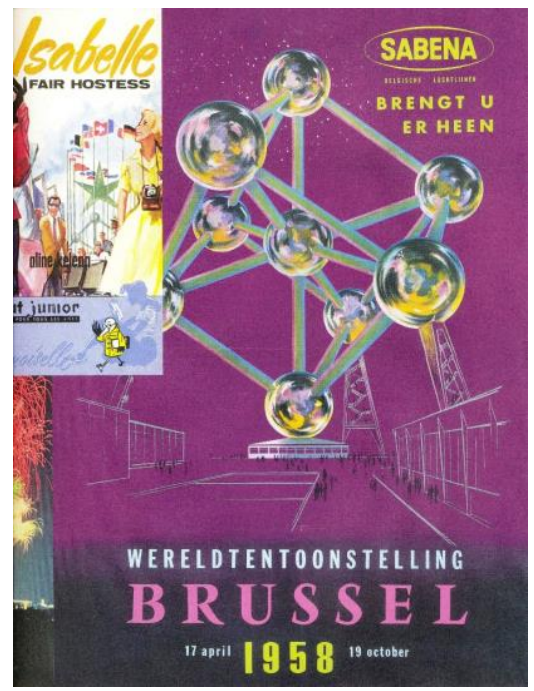

Figure 2 Poster Expo Bruxelles - 1958.

The activity of designers and engineering developments in particular, was favored by the intensification of contacts on a scientific and professional level, but also by the renewal of imaginaries and, in general, by public and private investments, operational fervor and a "competition" linked to the growing opening and progressive integration of markets, to the ideological confrontation between capitalism and the communist world [6] to decolonization [7], [8]. As never before and on an unprecedented scale in history, there were design opportunities that favored experiments and experiences and their diffusion in different areas of the world.

\section{THE STRUCTURAL WAVE}

It was a period of great momentum, both in theoretical and design achievements, located at the threshold of calculators [9]. This season has to be interpreted, far beyond exceptional episodes, within a broader framework that regarded the multiple fields of the structural vision [10]. We are dealing with a season that was boosted by renewed morphological and typological interests, artistic and scientific intersections as evidenced by the success of On Growth and Form ( first edition in 1917) by mathematical biologist D'Arcy Wentworth Thompson and experiences such as Frei Otto's Biologie und Bauen laboratory [11].

The high level of the reciprocal exchange between different disciplines, resulted into particularly prestigious expressions in the Italian scenario. For exemple we can recall the collaborations between the architect Gio Ponti and Pier Luigi Nervi (Grattacielo Pirelli/Pirelli Skyscraper a Milano), Nervi and the architect Luigi Moretti (Stock Exchange Tower in Montreal), the architect Angelo Mangiarotti and the engineer Aldo Favini and so on. This general situation led to important progress in several fields of application, metal structures and concrete - where the Italian best production focused on - but also tensile structures, morph-resistant structures, pneumatic structures.

Masterpieces such as the Palazzo delle Esposizioni in Turin conceived for the celebrations of the centenary of Italian unity (1961), the celebrated works for the Rome Olympics Games that benefited from the first world television broadcast (1960), the great infrastructures realized for the Autostrada del Sole were largely present on the professional magazins, as well as the Dorton Arena by polish-american architect Macej Nowicki and Fred Severud in North Carolina, the Air terminal of St.Louis (Minoru Yamasaki), the Kongresshalle of Berlin (Hugh Stubbins), the Mit's 
Kresge Auditorium (E. Saarinen), the CNIIT in Paris ( B. Zehrfuss, N. Esquillan and others), the Fernsehturm (Television Tower) in Stuttgart (Fritz Leonhardt) [12] ("Figure 3").

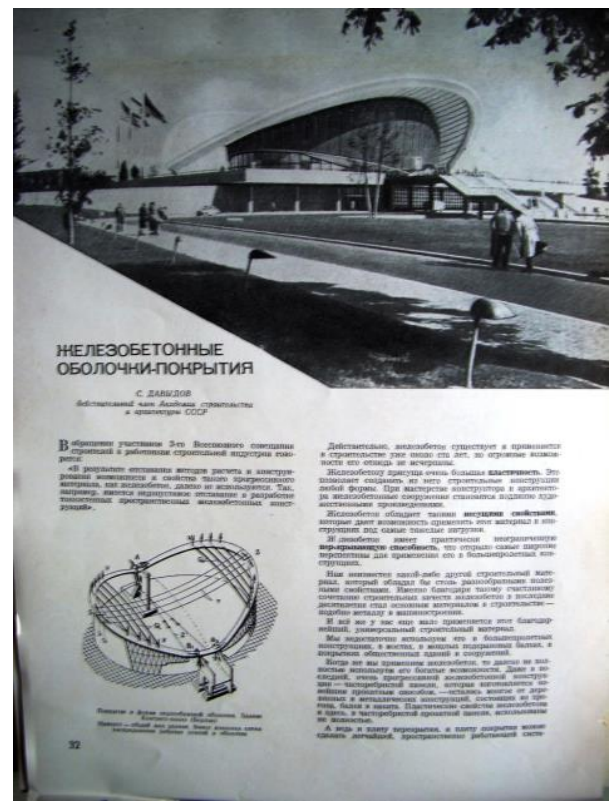

Figure 3 The Kongresshalle in Berlin on the pages of the magazine "Arkhitektura SSSR".

It appears useful to place and deepen the Italian contribution in this framework, not easy to focus because of the many gaps that hinder a comprehensive historical overview of engineering in the twentieth century, where Eugene Freissinet, Eduardo Torroja, Félix Candela, Felix Samuely, Ove Arup, Bernard Lafaille, René Sarger, Fred Severud, Fritz Leonhardt, Anton Tedesko and many others worked in, to better define its features and boundaries that led to a gradual marginalization after the pinnacle represented by the professional and academic recognition, especially for Nervi's and Morandi's work, and wrapped up in the "Twentieth Century Engineering" exhibition, organized at the MOMA museum in 1964.

The North American success of ltalian engineering, a largely developed topic at least for what concerns Nervi, was the most important aspect and a well-known page of a recognition that, between the 1950s and 1960s-1970s, had a global projection and interacted with different cultural frameworks.

This was the case of Latin America and the Peronist Argentina in particular: the first destination for many important figures of the Italian design culture, because of the favorable economic situation in the aftermath of World War II and the historical links between Italy and the South American Country. When the Italian engineers, together with other prestigious representatives of the national design culture, arrived in such a propitious scenario to assert their ideas and activities, favoured by the regulations, the labour force, the quick economic growth and partly by the technological development, many fruitful perspectives finally disclosed. Nevertheless, this arrival was also facilitated by the importance of the engineering and construction vision and the structural awareness typical of the local design cultures (as it is proved by personalities such as Eduardo Catalano, Eladio Dieste and Ubaldo Vilar) that participated in interdisciplinary projects, also fostered by peculiar tools to create and spread the debate.

This was, in fact, the context in which, after the Second World War, worked and published Giulio Pizzetti and Pier Luigi Nervi held lectures published in the book El lenguaje arquitectonico (facultad de arquitectura y Urbanismo, Buenos Aires, 1951) . Newly founded, the Faculty of Architecture of Buenos Aires awarded him the first of the many academic awards that he received abroad.

Anyway, from the Fifties onwards, for two decades, the presence of ltalian engineering in this and other parts of the world, would take considerable importance. It was the expression of dynamism of the Italian industry and entrepreneurship - in search of expansive possibilities within the framework of the possibilities imposed by the Cold War [13] - that would lead to remarkable episodes such as those witnessed by the partnership between the Olivetti company and Marco Zanuso, or large infrastructure constructions in steelconcrete mixed system such as those that characterize the work of Fabrizio de Miranda.

\section{LOOKING EASTWARD}

The contribution of the Italian engineering culture in the countries of Eastern Europe has drawn a marginal attention so far, even though it is highly interesting, because it allows a broader look to the1950's-1970's structural phenomenon. The honoris causa degree that Pier Luigi Nervi received in 1961 from the school of Warsaw Polytechnic was an emerging episode in the context of the attention that, in those years, with different nuances, the socialist countries paid to the Italian design culture. 
In some of these countries, because of recent developments and traditions, structural en.gineering was developing dramatically, also for ideological reasons. This is proved also by specialized magazines as "Architektura", "Projekt", "Deutsche Architektur", "Architektura CSR" "Architektura i urbanizm", "Architektura SSSR" that are, for the topics we are dealing with, no less interesting than their western counterparts "Architectural Forum", "Architectural Review", "Architecture d'Aujourd'hui", "Casabella", "Zodiac", "Domus" ("Figure 4").

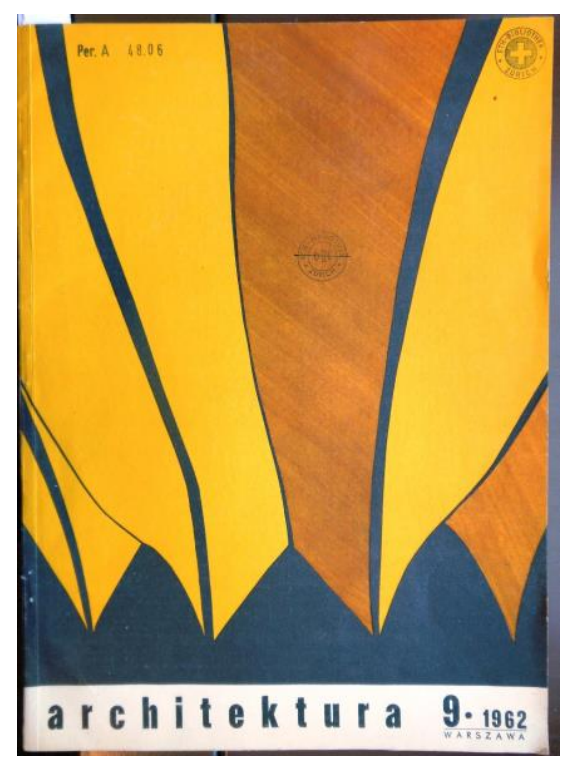

Figure 4 The Polish magazine "Architektura", no. 9, 1962.

The dialogue between architecture and engineering and the interest for new architectural forms whose birth was due to the development of construction techniques, lasted long, in the concerned period, in this part of the world. This interaction also had a climax until the 1960s-1970s, as it is proved by sometimes interesting design projects and constructions, even because these works were specific examples of an idea of urban planning that was linked to the gradual growth of industrial production.

The Soviet Union was on the front-line within this framework. The turning point, which was triggered by the de-Stalinization, where engineering, industrialization and the development of the reinforced concrete prefabrication were the core of the design theory, immediate.ly contributed to open up to international engineering organisations such as the Fédération Internationale de la Précontrainte and the Comité Eurointernational du Bèton, which constituted a meeting and sharing point for the international structural culture. In this context important italian specialists as Franco Levi and Riccardo Morandi were invited in the Soviet Union between 1956 and 1958 to discuss their work on developments in prestressed concrete [14].

The figure of Nervi, also in the Soviet Union, drew a very peculiar attention, among other protagonists of Western culture.

Nervi's work was already widely known in the USSR before the Second World War and it is enough to recall the pages (and the images) that Lazar Rempel' dedicated to him in his volume devoted to the Italian architecture of the fascist period [15]. But his work, which in the meantime had reached world fame and had undergone important developments in relation to the ferrocement technique and prefabrication, took on a very particular importance in the period of the Thaw and the revolution implemented by Khrushchev.

In fact Nervi's Costruire correttamente was rapidly translated into Russian [16], an operation that was evidently decided by the top brass, just a few months after the first Italian edition and perfectly in line with the American edition ("Figure $5 ")$.

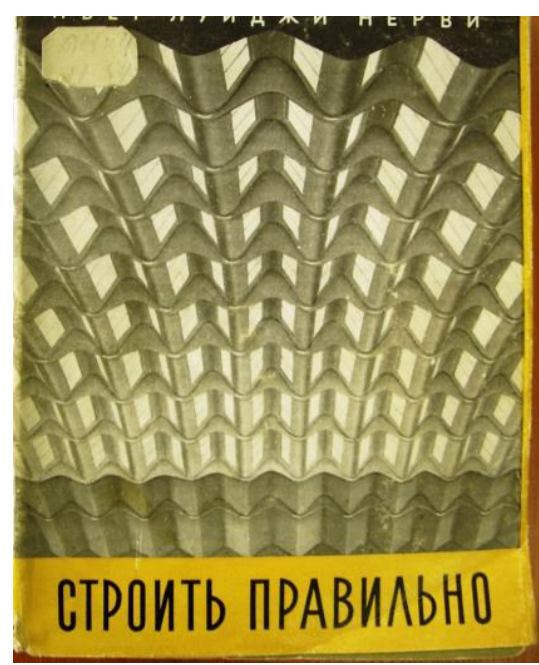

Figure 5 (BOOK COVER) Nervi P.L. Stroit' pravil'no. Gosudarstvennoe Izdatel'stvo po stroitel'stvu i architekture, Moskva, 1956.

What are even more relevant are the practical consequences of this timely attention. It is in fact more than likely that one of the projects presented and never realized (the Monumento della bandiera, 1932) - in this small but precious booklet was the inspiration (together with the mentioned erlier Stuttgart TV Tower) for engineer Nikolaj Nikitin 
for the design and the structural solution of the Ostankino tower, destined to represent one of the main symbols of the new post-Stalinist architecture and, in many ways, the latest, sophisticated legacy of the Palace of Soviet [17], [18].

Anyway, Pier Luigi Nervi was at the height of his international, global fame when his main monograph was published in Russian (1968) [19] ("Figure 6") and in this juncture, in which the USSR, was rapidly opening up to the recovery of the Soviet avant-garde and the developments of international design culture [20] the reference to the Italian designer's work, as it can be found in many articles and publications, was clearly functional, providing examples of a creative genius that perfectly fitted the most relevant themes concerning design at that time, able to join together expressiveness, structural evidence and construction reason. Nervi's lesson proved to be effective in designing industrial architecture and big-sized sports and social facilities, interpreted in the light of specific features of Soviet construction industry and typological horizons of its architecture.

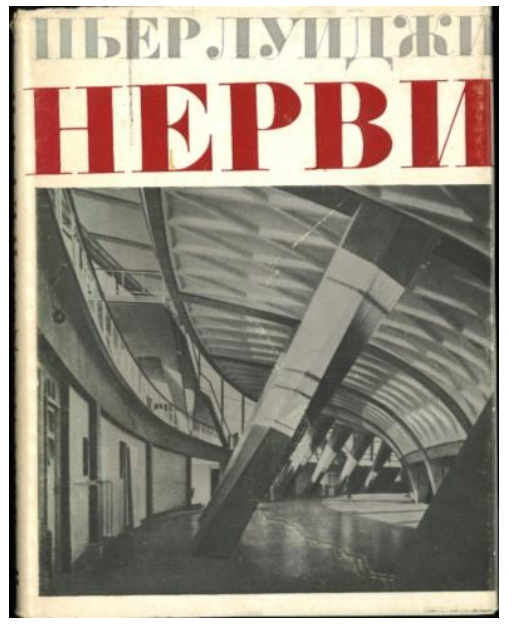

Figure 6 (BOOK COVER) E.K Ivanova, P.A. Kacnel'son, P'er Luidzhi Nervi, Izd. lit. po stroitel'stvu, Moskva, 1968.

Nervi obviously never worked in the Soviet Union, but the Nervi's lesson, apart from the Ostankino Tower, finds many intrepretations referable to different aspects, and to the most famous works of post-war research. If some projects of industrial buildings, carried out in the late $1950 \mathrm{~s}$ recall the constructive solutions in ferrocement of the Turin Exhibition Center, in other cases of public buildings the formal imprint of some masterpieces of the Italian engineer was resumed, adapted to the construction systems now dominant in the country. Two examples: the
Askhabad shopping center with static-construction modules clearly inspired by the pillars of the Palazzo del Lavoro of Italia '61 in Turin and, above all, one of the main and most interesting achievements of the 1980 Olympics: the "Druzhba" Olympic sports complex (D. Solopov, Ju. Bol'shakov, V. Tarasevich, V. Pontriagin, Ju. Rozovskii, L. Kharitonov, T. Rud', G. L'vov, E. Zhukovskii, V. Shablja, 1978-1979) whose compact centralized volume completed the whole of the Lenin stadium, providing an allusive reference to the sports hall in Rome, reinterpreted in the light of a different structural idea and organization of production and construction site ("Figure 7").

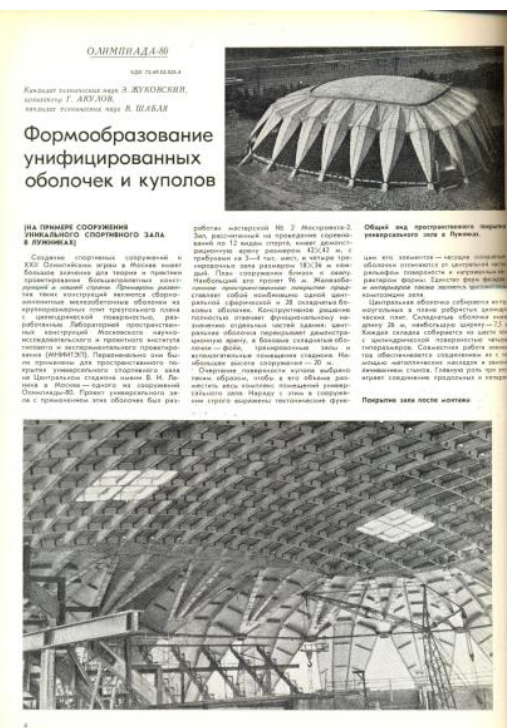

Figure 7 Page from the magazine "Arkhitektura SSSR", no. 2, 1979.

From the constructive point of view, the work was conceived as an assembly of large prefabricated elements that could have been tapped, with compositional variations, in the realization of different types of public buildings [21].

It was a very original translation of the ideas of Pier Luigi Nervi on the scale of the great building industrialization.

\section{CONCLUSION}

Between 1950s and 1970s, Italian engineering had considerable relevance and recognition and this fact constitutes one of the significant features - still little investigated today - of the history of architecture and design culture in the second half of the twentieth century. Joining the engineering and technological thrust and the search for new 
structural forms that characterize the development of architecture after the Second World War, the activity and success of Italian designers, first and foremost that of Pier Luigi Nervi, is characterized in particular by the original and recognizable approach to the design of reinforced concrete structures.

A no less important aspect of the international presence of Italian engineering was due to the intensification of scientific and professional contacts, particularly favored in Europe by deStalinization and to operational fervor and "competition" promoted by the growing opening and progressive integration of markets, to the ideological confrontation between capitalism and the communist world.

By tracing a general and concise overview of these developments in particular studied above all from the point of view of Nervi's success in the United States, the article has in particular intended to highlight the specific and original look and approach that characterizes the design culture of the socialist countries, in particular that of the Soviet Union since the years of the Thaw.

\section{AUTHORS' CONTRIBUTIONS}

This paper is independently completed by Alessandro De Magistris.

\section{REFERENCES}

[1] R. Banham, Stocktaking tradition and technology, in: The Architectural Review, vol. 127, no. 756, February, 1960, pp. 93-100.

[2] T. Iori, L'ingegneria del miracolo italiano (The engineering of the Italian miracle), in: Rassegna di Architettura e di Urbanistica (Review of Architecture and Urban Planning), 2007, vol. XLI, no. 21-22, pp. 33-59 [in Italiano].

[3] C. Olmo, C. Chiorino (eds.), Pier Luigi Nervi. Architecture as a Challenge (Pier Luigi Nervi. Architettura come Sfida). Civa, Milano, Bruxelles, Silvana Editoriale, 2010, pp. 119133 [in Italiano].

[4] C. Siegel, Structure and form in modern architecture (Strukturformen der Modernen Architektur). München, Callwey Verlag, 1960 [in German].
[5] K. Sigel', Structure and form in modern architecture (Struktura i forma v sovremennoi arkhitekture). Moscow, Stroiizdat, 1965 [in Russian].

[6] A. Iriye (ed.), Global Interdependence: The World after 1945 (A History of the World). Cambridge, The Belknap Press of Harvard University Press, 2013.

[7] L. Stanek, Architecture in Global Socialism. Eastern Europe, West Africa, and the Middle East in the Cold War. Princeton, Princeton University Press, 2020.

[8] O.A. Westad, The Global Cold War: Third World Interventions and the Making of our Times. Cambridge, 2005.

[9] A. Picon, Digital Culture in Architecture. An Introduction for the Design Professions. Basel, Birkhauser, 2010.

[10] P. Desideri, A. De Magistris, C. Olmo, M. Pogacnik and M. Sorace (eds.), The structural conception. Engineering and architecture in Italy in the 1950s and 1960s (La concezione strutturale. Ingegneria e architettura in Italia negli anni cinquanta e sessanta), Torino, Allemandi, 2013 [in Italiano].

[11] W. Nerdinger (ed.), Frei Otto. The complete work. Build easily - design naturally (Frei Otto. Das Gesamtwerk. Leicht bauen Natürlich gestalten). Basel, Birkhauser, 2005 [in German].

[12] J. Kleinmanns, C. Weber (eds), Fritz Leonhardt 1909-1999. The art of construction (Fritz Leonhardt 1909-1999. Die Kunst des Konstruierens). Stuttgart, London, Axel Menges, 2009 [in German].

[13] A. Castagnoli, The economic cold war. Italy and the United States 1947-1989 (La guerra fredda economica. Italia e Stati Uniti 19471989). Roma-Bari, Laterza, 2015 [in Italiano].

[14] M. Marandola, The prestressed construction (La costruzione in precompresso). Milano, Il Sole 24 ore, 2009 [in Italiano].

[15] L.I. Rempel', Architecture of post-war Italy (Arkhitektura poslevoennoi Italii). Moscow, Izdatel'stvo Vsesoiuznoi akademii arkhitektury, 1935 [in Russian].

[16] P.L. Nervi, Build correctly. Ways of development of reinforced concrete structures 
(Stroit' pravil'no. Puti razvitiia zhelezobetonnykh konstruktsii). Moscow, Gosstroiizdat, 1956 [in Russian].

[17] A. Bronovitskaja, The Pinnacle of Soviet modernism, in: Territory (Territorio), no. 67, 2013, pp. 67-71.

[18] A. De Magistris, For a history of the competition of the Palace of the Soviets (Per una storia del concorso del Palazzo dei Soviet), in: Nice house (Casabella), no. 838, 2014, pp. 58-79 [in Italiano].

[19] E.K, Ivanova, P.A. Kacnel'son, Pier Luigi Nervi (P'er Luidzhi Nervi). Moscow, Stroiizdat, 1968 [in Russian].

[20] I. Chepkunova, P. Strelcova et al. Pioneers of soviet modernism. Architecture and urban planning (Pionery Sovetskgogo Modernizma. Arkhitektura i Gradostroitel'stvo). Moscow, Kuchkogo Pole, 2020 [in Russian].

[21] E. Zhukovskii, G. Akulov, V. Shablia, Formation of unified shells and domes (Formirovanie unifitsirovannykh obolochek i kupolov), in: Architecture of the USSR (Arkhitektura SSSR), no. 2, 1979, pp. 6-8 [in Russian]. 